NeurociênCIA

\section{Anestesia geral não é um sono profundo}

Emery Brown, primeiro autor da revisão "Anestesia geral, sono e coma", publicada no prestigioso periódico científico The New England Journal of Medicine (Vol. 363, Dezembro 2010), trabalha no mesmo local onde aconteceu a primeira demonstração pública de cirurgia sem dor. Foi em 1846, no anfiteatro hoje conhecido como Ether Dome, no Massachusetts General Hospital, em Boston, que o paciente inalou éter administrado pelo médico William Morton enquanto o Dr. John Collins Warren fazia a cirurgia. Atualmente, 60 mil pessoas por dia recebem anestesia geral para cirurgia só nos Estados Unidos.

Inúmeros avanços têm sido observados na área, tanto com melhorias nos anestésicos, treinamento médico, sistemas de delivery de drogas, quanto com evoluçōes nos sistemas de monitoramento do estado do paciente durante a cirurgia. No entanto, "como as drogas anestésicas induzem e mantêm os estados comportamentais da anestesia geral é uma questão importante da medicina e da neurociência", escrevem os autores. A revisão discute as características clínicas e neurofisiológicas da anestesia geral e suas relações com sono e coma, focando nos mecanismos neurais da inconsciência induzida por determinadas drogas anestésicas intravenosas.
Ao comparar a atividade cerebral durante anestesia, sono e coma, os autores ressaltam que o cérebro anestesiado se parece com o cérebro de paciente em coma. Embora muitos médicos usem o termo "sono" para explicar a anestesia aos seus pacientes, "a anestesia geral é, de fato, um coma reversível induzido por drogas", escrevem. A similaridade entre anestesia geral e coma mostra quão profundamente a anestesia debilita a atividade cerebral. "[Isso] talvez explique porque alguns pacientes não recuperam completamente a consciência muitas horas após [terem recebido] a anestesia geral e porque a disfunção cognitiva pós-operatória pode persistir em pacientes mais velhos por muitos meses", concluem os autores do estudo.

FISIOLOGIA Segundo os autores, a anestesia geral é mantida por meio de uma combinação de agentes hipnóticos, inalatórios, opioides, relaxantes musculares, sedativos e drogas cardiovasculares, junto com suporte de ventilação e termo-regulação.

Drogas anestésicas induzem inconsciência ao alterar a transmissão de sinais neurais em locais múltiplos no córtex cerebral, tron- co cerebral e tálamo. Os opioides, por exemplo, inibem a liberação do neurotransmissor acetilcolina em diferentes locais do cérebro e da medula espinhal. A acetilcolina medeia, junto com outros neurotransmissores, a transmissão sináptica rápida no sistema nervoso central. No entanto, apenas ela está presente nas sinapses rápidas das junções neuromusculares.

Entender melhor as similaridades e diferenças entre anestesia geral, sono e coma pode levar a novas abordagens para anestesia geral "baseadas em novas maneiras de alterar a consciência, prover analgesia, induzir amnésia e prover relaxamento muscular", concluem.

Cristina Caldas 